\title{
YOUTH CRIME AS A AVAILABILITY PROBLEM ${ }^{16}$
}

\author{
Marcela TITTLOVÁ \\ Institute of Public law, Faculty Law PEU
}

\begin{abstract}
Criminal behavior of youth is a constantly current problem. It is not a new problem, a new one emerging and exploring. In the historical context, we meet him quite early. Likewise, we are punished with the possibilities and attempts to solve it. As we are currently talking about a very topical issue, it is clear that this phenomenon is not quite at the professional and legal level. Instead, rather than the consequences, it is necessary to examine the causes of the criminal behavior of youth. Often, they are conditioned by the criminal behavior themselves against the children taking these patterns and models into their behavior and their reactions. From the point of view of the possibilities of solution, then we get completely into other areas and other spheres.
\end{abstract}

\section{KEYWORDS}

youth, criminality, causes of crime, consequences of crime.

\section{JEL CLASSIFICATION}

K10, K20, K30.

\section{INTRODUCTION}

Juvenile delinquency is a concomitant of any transforming society. The negative socio-pathological phenomenon disrupts the harmonious development of society, threatens the fundamental rights and freedoms of the individual, the company produces a feeling of fear and insecurity. Youth crime continues to be a problem because it has failed to completely eliminate its causes and to change the conditions to protect the company and the individual. Youth crime is considered a multidisciplinary issue that has aspects of social and personality, as well as sociological, psychological, educational and criminal law.

\section{HISTORICAL EXCURSION PHILOSOPHICAL SCHOOLS}

While exploring seeking to clarify the causes of crime dates back to the end of the last century research focused exclusively on juvenile delinquency date back much later. The first research arose until after World War II. And those specific investigations, however, followed the earlier views and focused on factors dual nature.

\footnotetext{
${ }^{16}$ This study was supported by the Agency for promotion of research and development on the basis of the Contract No.
} APVV-15 - 0644 
The first group includes the so-called exogenous factors, existing outside ,,perpetrator”, primarily factors in social and community areas, which had a decisive influence over the conduct of the offender. The second group consisted of endogenous factors, linked directly to the individual offender that were trapped in the offender. Were factors here included particularly in the field of psychology, biology and medicine.

Historical development of views on the causes of crime helps us better understand our present and current views on crime.

Positivist school, which was established in the last quarter century of the 19th century in Italy taught that crime is defined by two series of causes. These are the causes of internal, arising from the nature and heritage of the offender. Then there are external causes, comprising physical and especially in the social environment in which the offender lives. Enrico Ferri taught that every crime is the result of three groups of factors: anthropological, physical and social. In a social setting, crime is strongly dependent on these factors. Ferri is the law of criminal saturation. Founder of the positivist school, an Italian physician Cesare Lombroso, examined psychophysical, biological and social factors of juvenile delinquency. Its conclusion was based on research results 79 minors less than 12 years, located in the detention centers. At the same time with them he compared a group of 160 trainees who have previously committed any crime. Lombroso came to the conclusion that the moral defects in children exhibit much stronger than in adults, but they have the same cause. It arises primarily from predisposition inheritance. Education and other external factors not under Lombroso absolutely no meaning. Positivists tried also a new typology of offenders looking for more general types. Their position in the offenders who were mentally ill were perpetrators of habit, casual, and perpetrators of affect. ${ }^{17}$

Protecting the Company can be secured by positivists preventive measures. Ferri in support of its opinion example that became famous: In a dark street are committed many crimes. To prevent them, you only need to illuminate the street. This is a sensible and economical to let police officers patrolling the street and build a prison for criminals. ${ }^{18}$

Sociological trends in criminology give crucial in crime of external factors and conditions in society. They show the impact of various factors of social life, such as unemployment, poverty, poor existential conditions, alcoholism and underline the need to combat these criminal factors. Emil Durkheim, the founder of the French sociological school, tried to prove that crime as a pathological social phenomenon is something normal, associated with a company with a given culture. The center of his attention are no longer just as they did at Ferri, individual, empirically detected factors crime. He understands crime as a social phenomenon, having its legality, which is nothing accidental and arise from accidental causes. On the contrary, it is with Durkheim normal phenomenon, arising from the regular operation of the company. Anomie is therefore a mechanism that produces in a given society conflict situations leading to crime when his individual criminal behavior, refuses to abide by recognized and established standards and rules of human behavior.

Sociologically oriented theory of the causes of crime have achieved the largest expansion in the United States. These theories, which show the main causes of serious youth crime and disorganization of adults in American society and differentiation pooling, are actually modifications mentioned Durheims ideas. The company as a result of the weakened integrative function of culture extends to various groups, recognizing their own scale of values and forming their own subculture. Thus, neither individuals directly related to each other do not recognize the same values, do not

\footnotetext{
${ }^{17}$ SEJČOVÁ L'., Deti, mládež a delikvencia, Bratislava: ALBUM, 2002, p. 43

${ }^{18}$ SUCHÝ O., Praha: MELANTRICH, 1972, Mládež a kriminality, p. 24
} 
respect the same standards of conduct, getting into conflict situations. It is creating state of social disorganization, in production pathologies such as alcoholism, crime, suicide rate. One of the main theories dominating in American criminal sociology during the last twenty years, Sutherland's theory of Differential association. Sutherland also understand crime as a socio-cultural process that is part of each company. Individual criminal behavior is explained by the process of which this behavior stems are not different from the process of normal human behavior. Criminal behavior occurs in a social system Freedom of Association, as well as normal behavior. Both of these systems are social worlds, creating groups, the association of shorter or longer duration, were tightening the appropriate scale of values recognized. And it is, according to Sutherland, just criminals associative system in which the developing personality of a criminal offender. The same basic processes of learning and socialization that characterize the integration of personality in society, characterize the criminal personality. A criminal is a member of associations or groups that it considered normal "member his" society. Also here is the root cause of crime social disorganization. Types of individual sectors, which are among them conflict with each other. Sutherland sees crime as a learned behavior normal human beings who are the meaning of their existence in conflict situations caused by social disorganization. Therefore no longer Lombrosotype native criminals, but , normal "individuals who commit crimes in the conflict social situations. Typical is the pessimism and hopelessness of these theories. ${ }^{19}$

\section{HISTORICAL EXCURSION IN THE POLITICAL ARENA}

All human societies have had a standard specifying the desired behavior of people. It is a broad set of written and unwritten rules and customs. Standards matter most, are assigned penalties applied when crossing generally known limits. Standard and penalties are determined by value said stops of a company, the spirit of the time. ${ }^{20}$ The concept of standards and appropriate sanctions in the West Country and historically variable the understanding of standards and related sanctions in Western culture we can follow different trends. Standards codified receive similar laws. Meaning practices decreases. Guarantor formulation of laws and their application becomes a state, unlike the Middle Ages, when the legal procedure of blood revenge, which carried the victims' relatives. Performance rights were later covered by the aristocracy and privileged places. Today, the state guarantees treatment of the accused, the course of judicial proceedings and imprisonment. Laws gradually begin to apply to all equally. In ancient times and the Middle Ages crimes judged as appropriate to the social situation and the penalties they were so stringent, which was less socially engaged person who is guilty. Punishment ceases to be public, and until recently was the most common form of imprisonment. In recent decades, developing alternative penalties that extend the range of sanctions and, in some cases, respect the interests of victims and also save the exchequer because the prison is now the most expensive penalties applied. Modern states have been building up extensive bureaucratised apparatuses for the detection of crime, the prevention and sanctioning. For example, at present it falls criminal youth within the remit of several ministries and organizations dependent on them. Gives rise to various detention centers, social reintegration and diagnostic centers. In the sphere of crime is committed by many non-governmental organizations that cooperate to varying degrees with the state the are many departments that deal with or specify the different areas of crime $^{21}$.

For us in the past, not all trends Western states be enforced because they lacked facilities democratic political system. After the change of the social regime in 1989, our country suddenly became a democratic state is trying to cope up with Western democratic states. Since then, we see that both in prevention as well as the oppressed juvenile delinquency consistently designed and

\footnotetext{
${ }^{19}$ SUCHÝ O., Praha: MELANTRICH, 1972, Mládež a kriminality, p. 24

${ }^{20}$ MATOUŠEK O., MATOUŠKOVÁ A., Praha: Portál, Ltd., 2011, the Youth and Delinquency, p. 68

${ }^{21}$ FIRSTOVÁ J., Plzeň: Aleš Čeněk, 2014, Kriminalita mládeže v sociálních souvislostech, p. 11
} 
enforced measures that still work well elsewhere, in our country are not connected to the corresponding historical development or lack the necessary background in public understanding, of opinion experts or the priorities of the political scene. Despite this handicap in our public debate began. The focus became, as in other countries, the sense of imprisonment and the effects of this punishment. Building prisons wanted to create a place where they could isolate those citizens who embody evil and pose for the rest of danger or threat. The prison was and is justified with as a means of removing offenders from committing further crimes. In the 19th century began to also consider whether or not the prison inmates to work educationally.

Numerous independent studies have been found, however, that once the juvenile and adult offender returns after serving a sentence of imprisonment to freedom, the probability that it will continue to conduct criminal will not fall, but rise. The prison is therefore no doubt institution that actual prisoners although prevented from committing a crime, but in the future a substantial part of preparing to commit another crime. We can therefore conclude that the sanctions applied to juvenile increase the likelihood of criminal behavior in adulthood. ${ }^{22}$

Adverse and after a few years in prison irreparable effects on the juveniles are now in western countries widely recognized a man whose socialization just starting. Therefore, several countries legislation limits the period of detention of minors less than human borders. ${ }^{23}$

\section{HISTORICAL EXCURSION LAWS}

The following summary does not provide all the relevant laws and documents referring to the fact that when working with youth at risk are used most frequently:

a.) Act on Criminal Justice of the youth of 1931- prepared already in the days of the AustroHungarian Empire, set the age of criminal responsibility to 14 years,

b.) Act on the protection of children from inappropriate entertainment from the 1922- defend youth participation in gambling, dances, banning young people to smoke and drink alcohol

c.) Act on the right of a family of 1949- introduce the same rules both parents to children

d.) Act on social and legal protection of children from 1952- up the Office for the Protection of youth as judicial authorities, civil law courts in every district. These bodies could independently from the courts to decide on the placement of children in institutional care

e.) Criminal Code and the Criminal Procedure Act 1950- increased the age of criminal responsibility at 15 years young, adolescents allows the use of protective care and protective treatment

f.) The Education Act 1953 defines the types of after-school educational establishments. They were orphanages, children's homes with higher educational care, retaining youth homes and homes with special care.

\section{CONSCLUSIONS}

Preventing youth crime is a complex interdisciplinary problem. It is obvious that the coordinated and systematic human to operate on multiple pages is, the success of our prevention efforts more realistic. Prevention activities should be but focus mainly on the local level. Right here it should be no more effective search of young people requiring help create functional models of prevention activities.

\footnotetext{
${ }^{22}$ SEJČOVÁ L., Deti, mládež a delikvencia, Bratislava: ALBUM, 2002, p. 30

${ }^{23}$ MATOUŠEK O., MATOUŠKOVÁ A., Praha: Portál, Ltd., 2011, the Youth and Delinquency, p. 69
} 
Among experts to work with delinquent youth in recent years, it is thought that more effective at preventing crime than the perpetrators after the commission of the offense as to punish. Many times it has been shown that only indiscriminately repressive approach to tackling crime does not bring the desired result.

Repressive component of criminal policy is obviously still necessary, but it should nevertheless be considered as "ultima ratio", that is just something that started off as a last resort solution to the problem. Still has to be a balance between the application of prevention and repression, and used all the possibilities for preventive action and social reintegration to not have to commute to the use of extreme repressive means of criminal law. In other words, it is necessary to look for such instruments of action for members of society to be more or less like itself to avoid antisocial, thus the instruments of preventive action have been if it were possible, suitably tailored to their individual needs and the needs of society. This is particularly true in the process of socialization of young people, which should play a preventive effect of a dominant position.

Preventing youth crime in recent decades considerable attention, leads to the formation of various prevention programs through which crime prevention is put into practice. The reasons for this effort are evident, they aim to capture the problematic behavior of children and youth in the bud and to guide it in the desired direction. The problem is usually that prevention programs are either applied excessively or inadequately. It is therefore necessary to coordinate the various prevention activities, get them to a functional system. Without systematic and coordinated effort it will reduce the effectiveness of the action, in some cases it becomes counterproductive. For this reason, underway since the seventies coordination efforts of these interventions on a systemic approach to the whole issue and in developed countries, are designed for different procedures, methods, systems and crime prevention.

\section{REFERENCES}

FIRSTOVÁ J., Plzeň: Aleš Čeněk, 2014, Kriminalita mládeže v sociálních souvislostech. MATOUŠEK O., MATOUŠKOVÁ A., Praha: Portál, Ltd., 2011, the Youth and Delinquency SEJČOVÁ L., Deti, mládež a delikvencia, Bratislava: ALBUM, 2002

SUCHÝ O., Praha: MELANTRICH, 1972, Mládež a kriminality. 